\title{
BPM and ECM: Similarities, differences, conceptual, and technological limits
}

\author{
BPM e ECM: similaridades, diferenças e limites \\ conceituais e tecnológicos
}

\author{
Marco Aurélio de Souza MENDES' \\ Marcello Peixoto BAX²
}

\begin{abstract}
Enterprise information architectures still do not deliver all the value that comes from integrating structured and unstructured information. Enterprise Content Management and Business Process Management were developed as autonomous disciplines. Thus, Enterprise Content Management still occurs without formally considering the business processes that generate and manipulate content, while Business Process Management initiatives arise without a documented treatment of materials produced by the processes. The non-integrated approach to these disciplines collaborates to reduce the potential benefits expected in Organizational Change Management programs. In such context, the article discusses the interrelation between Business Process Management and Enterprise Content Management, approaching from a historical view of these disciplines, their conceptual limits, technological support, and dialogues that would benefit both initiatives. The paper contributes to clarify a question still vague in the field of Information Management, which is how to integrate Business Process Management and Enterprise Content Management treating structured and unstructured information in a unified manner. It discusses how to approach this issue in a broad scope of IM by combining the concepts of Enterprise Content Management and Business Process Management. Based on a literature review, the paper analyzes and synthesizes experiences in Enterprise Content Management and Business Process Management acquired in the context of a project carried out in a Power Sector Company. The article reveals problems in separating approaches to Enterprise Content Management and Business Process Management. It shows the importance of an effort for integration and presents three instruments that promote the linkage of the two initiatives, approximating process offices and analysts' information.
\end{abstract}

Keywords: Archival sciences. Business process management. Document management. Enterprise content management.

\section{Resumo}

Arquiteturas de informação corporativas ainda não entregam todo o valor que advém da integração de informações estruturadas e não estruturadas. O artigo discute formas complementares de abordar essa questão por meio da integração dos conceitos de Gestão de Conteúdo Corporativo e Gestão por Processos de Negócios, que se desenvolveram até hoje como disciplinas autônomas. Iniciativas de gestão de conteúdo corporativo ainda ocorrem sem considerar formalmente os processos de negócio que geram e manipulam conteúdos. Ao mesmo tempo, iniciativas de gestão por processos de negócio ocorrem sem um tratamento formalizado dos conteúdos produzidos por esses processos. A abordagem não integrada das duas disciplinas colabora para reduzir os benefícios potenciais esperados da arquitetura de informação corporativa e dos programas de gestão de informação. O artigo discute a inter-relação entre ambas, abordando desde a visão histórica dessas disciplinas, seus limites conceituais e suporte tecnológico, até a necessidade de

1 Universidade Federal de Minas Gerais, Faculdade de Ciências Econômicas, Centro de Pós-Graduação e Pesquisas em Administração. Belo Horizonte, MG, Brasil.

2 Universidade Federal de Minas Gerais, Escola de Ciência da Informação, Departamento de Teoria e Gestão da Informação. Av. Antônio Carlos, 6627, Pampulha, 31270-901, Belo Horizonte, MG, Brasil. Correspondência para/Correspondence to: M.P. BAX. E-mail: <bax@ufmg.br>.

Support: Coordenação de Aperfeiçoamento de Pessoal de Nível Superior (Process n’ 88881.120772/2016-01).

Received on January 11, 2016, final version resubmitted on April 12, 2017 and approved on May 30, 2017.

Como citar este artigo/How to cite this article

Mendes, M. A. S.; Bax, M. P. BPM and ECM: Similarities, differences, conceptual, and technological limits. Transinformação, v. 30, n. 1, p. 95-105, 2018. https://doi.org/10.1590/2318-08892018000100008 
diálogo para benefício mútuo. O artigo esclarece, assim, uma questão teórica ainda vaga: como se podem tratar de forma integrada as duas disciplinas e unificar, em âmbito corporativo, informação estruturada e não estruturada. À luz de uma revisão da literatura, buscou-se analisar e sintetizar experiências em Gestão de Conteúdo Corporativo e Gestão por Processos de Negócios adquiridas no contexto de um projeto de gestão de conteúdo corporativo em empresa do setor elétrico. O artigo revela problemas de abordagens desintegradas das disciplinas e mostra a importância do esforço de integração das duas iniciativas, apresentando três instrumentos complementares que promovem o seu enlace, ao mesmo tempo que aproxima escritórios de processo e analistas de informação.

Palavras-chave: Arquivologia. Gestão de conteúdo corporativo. Gestão documental. Gestão por processos de negócios.

\section{Introduction}

Enterprise Content Management (ECM) and Business Process Management (BPM) are tools used to promote Organizational Change Management (OCM) programs in organizations. The first instrument seeks to address the life cycle of content management, such as physical files, electronic documents, and other media, from its capture to its storage, and eventual disposal. The second seeks to address the improvement of organizational business processes, i.e., the modeling of existing processes, automation and enhancement of business indicators of these processes.

Supported by Information Technology (IT) platforms, ECM and BPM have developed as autonomous knowledge bodies. ECM is mainly promoted by Information Science professionals, while BPM is designed by their counterparts from Business and Production Engineering. The effect of their independent development is that Change Management programs related to content management and process management bring the distinct and separate methodological vision particular to each domain.

Enterprise Content Management practitioners implement content management programs within a strictly functional view, inventorying, organizing, and preserving the files of a specific area in an organization. The implementation of ECM with this operative view tends to ignore how records are produced and consumed collaboratively by several different areas, which may imply in redundancies and failures in these implementations. At the same time, BPM professionals seek to improve business processes and, in several opportunities, do not treat data and documents produced by these processes with the methodological rigor needed by their curators (archivists and librarians). However, the search for the improvement of business processes without considering the documentary life cycle and record management instruments, such as document classification plans and timetables, can generate repositories of isolated, disorganized and difficult to maintain corporative documents (silos). By consuming and producing records without communication with ECM, business processes do not guarantee corporate visibility to them. Similarly, processes must be able to fetch and save documents in the corporate database (ECM repository), not just locally. Indeed, the interest of such an integration between ECM and BPM is in line with the motto: "Process without content serves no purpose and content without process goes nowhere" (Larrivee, 2016, p.8).

One aspect that makes the BPM $\times$ ECM relationship complex is that these disciplines have been worked in information technology through their specific technological platforms. Today, there are dozens of tools for content management and many others for business processes management. Some of the BPM tools provide document management functions, while ECM tools provide facilities for modeling processes and information flows. These "grey areas" generate misunderstandings and situational conflicts between BPM and ECM professionals. It is not uncommon to find BPM and ECM advocates that claim their tools also perform the functions of the other. It is also not unusual for some of these tools to be used beyond their conceptual boundaries, with often inadequate results.

In light of a literature review, we sought to analyze and synthesize experiences in ECM and BPM acquired during the realization of an ECM project in an electric company. The article aims to deepen the debate about the relationship between the BPM and ECM disciplines, performing a historical analysis of these subjects, their relations, similarities, fundamental differences, and conceptual boundaries. We also stress the importance of an effort for the 
integration of these disciplines and present three complementary instruments that promote their linkage, bringing process officers and information analysts together. We begin the article giving an overview of the ECM and BPM disciplines. Then we present the IT platforms for ECM and BPM and discuss these subjects based on evidence gathered from a concrete case experienced by the authors. Furthermore, we show three unifying instruments in the business perspective and present some conclusions of the study.

\section{Enterprise Content Management and Business Process Management}

Enterprise Content Management is a set of practices, processes and methods that aim to capture, classify, manage, store, preserve, deliver, and discard content in organizations. ECM integrates Records Management (RM) and Electronic Document Management (EDM) within a unified domain. ECM extends both RM and EDM by including not only paper and electronic documents, but several other information media in its management processes, dealing with both structured (database) and unstructured (texts, images, or videos) formats.

Enterprise Content Management knowledge is organized by some associations, such as the Association for Information and Image Management (AIIM) and the Data Management Association (DAMA). It is also standardized by ISO 15489 (International Organization for Standardization, 2001) and involves initiatives as:

- Planning information needs in an organization.

- Identifying information that needs to be obtained.

- Creation, approval, and implementation of policies and document practices.

- Developing short and long-term storage plans that include physical and digital documents.

- Controlling access to documents both internally and externally, balancing business confidentiality requirements, data privacy, and public access.

- Creating document management policies in accordance with legal requirements (classification plans and timetables).

Business Process Management is an approach of management that seeks to understand and improve the performance of firms by acquiring knowledge, modeling and improving their processes. It started in the 1920s through quality management programs, focusing on the improvement of the tasks. It has been further developed in movements such as organizational reengineering in the 1980s and 1990s. The third wave of process management establishes and consolidates the term BPM, now popularized as a central approach to business process management. Figure 1 briefly presents this historical view.

According to the BPM Commom Body of Knowledge (Antonucci et al., 2009), business process management is a disciplined approach to identifying, designing, executing, documenting, measuring, monitoring, controlling, and improving business processes (automated or otherwise) to achieve target results, consistent and aligned with the strategic goals of an organization. The areas of knowledge foreseen in this body of knowledge include:

- Process analysis: methods for understanding processes in an organization.

- Process design: methods for specifying new or improved processes.

Process performance management: methods to provide information for process adjustments to meet business goals.

- Process transformation: methods for Change Management through the implementation of the results of process analysis and design.

- Corporate process management: methods for orchestrating knowledge areas in an integrated process view. 


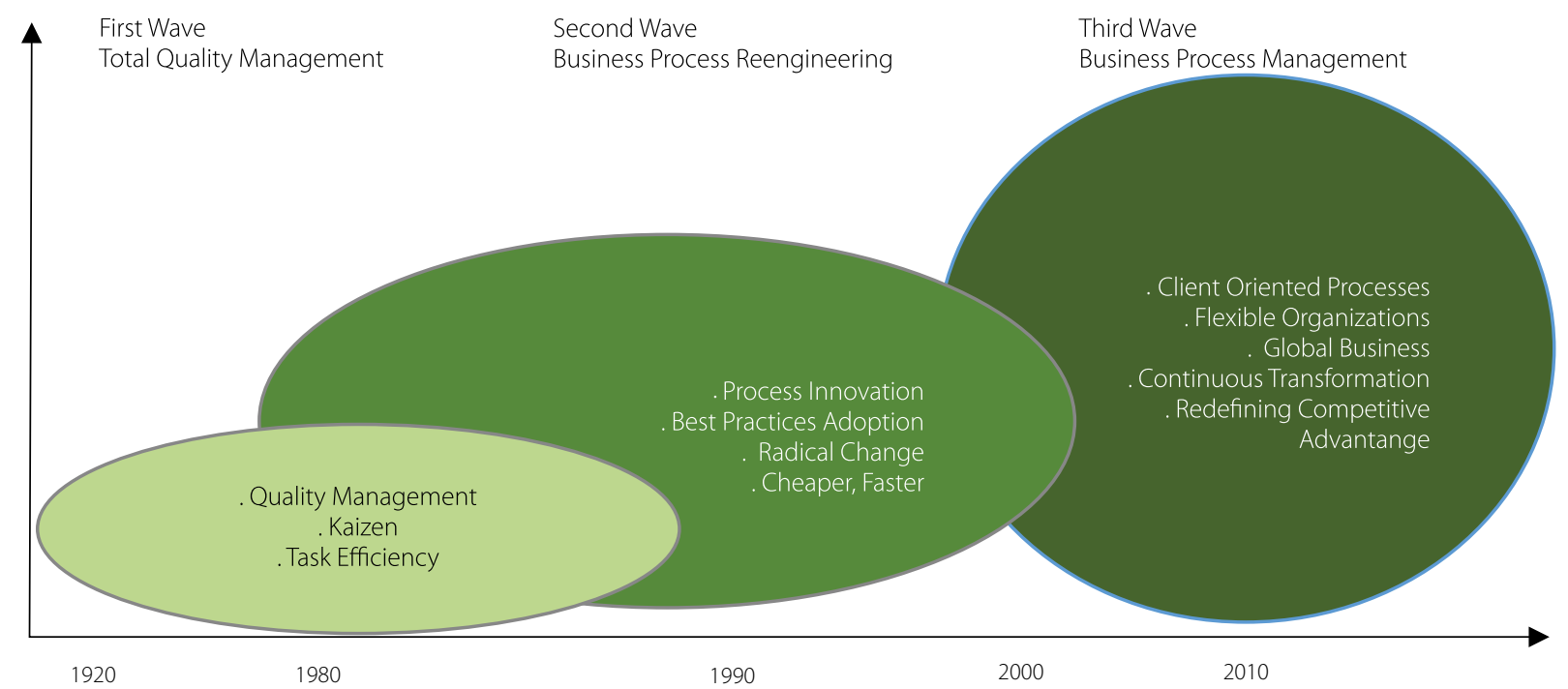

Figure 1. Historical view of Business Process Management.

Source: Prepared by Authors (2016), adapted from Smith (2003).

BPM technology: technologies for enabling BPM discipline through modeling, automation, simulation, and process management tools suites. These suites are called Business Process Management Suites/System (BPMS).

\section{Information Technology platforms for ECM and BPM}

In the field of Information Technology (IT), a platform is a productivity accelerator composed of a set of components, libraries, and software and hardware frameworks that aim to facilitate human work in organizations. The term ECM has been used in IT since the early 2000s to designate a platform for managing electronic documents. The term BPMS, also originated at the time, has been used to designate suites of tools for modeling, automating, monitoring, and managing business processes.

As seen above, ECM can be described as a platform that supports virtually all types and formats of content throughout its lifecycle, including capture, classification, access, management, custody, preservation, and disposal. The main components of an ECM suite include features designed to:

- Document management to allow saving, versioning, providing control access, and searching services for business documents.

- Record management to allow long-term archiving and automation of retention according to the public and private regulations of each sector.

- Sort, index, and manage Web content from a central base repository.

- Work image processing applications to capture, transform, and manage images of paper documents.

- Obtain social content for document-sharing and collaboration for project teams and knowledge management processes.

- Guarantee content flow to support document flows, business processes, task assignments, and audit trails of document manipulation.

- Shelter complementary components, such as mobile applications, digital asset management, research, active analysis, and integration with portals, ERP and CRM. 
The term BPMS is popularized in IT as an acceleration platform to support the third wave of process management, and it is technically composed of components for:

- Processing modeling in formal notations, with emphasis on Business Process Modeling Notation (BPMN).

- Simulating business processes for the previous performance analysis of the processes proposed in the drawing area.

- Automating processes through service orchestration and integration with data sources, applications and legacy systems.

- Registering and repository of processes for classification, organization, and search of process.

Beginning in 2011, alternative terminology for BPM suites was proposed by some market analysis institutes such as the Gartner Group, called Intelligent Business Process Management Suites (IBPMS) (Silva; Martins, 2013). The role of iBPMS is to meet the business capability of intelligent operations, which should enable rapid responses in dynamic environments by means of the integration of processes, data, and applications. According to Schulte (2011) and the Gartner Group (2012), an iBPMS should contain all 10 key capabilities:

- An environment for the graphical composition of the processes design, their activities and artifacts.

- An engine to orchestrate process execution and to guide the progress of structured or unstructured work.

- Managing interaction with content to support work progress based on changes in the process content itself (such as documents, images, and audio). This can be done natively or through integration with other ECM tools.

- Managing human interaction to enable natural interaction of people and the processes they are involved in.

- Connectivity between processes and resources that control them, such as people, systems, data, events, goals, and performance indicators (KPIs).

- Active analysis to monitor the progress of activities real time, analyze activities and changes in the process, and everything else involved.

- ON-demand analysis to enable decision support or automatic decisions based on predictive analytics or technology optimization.

- Management of business rules to guide and implement agility in the process and ensure adherence to the business.

- Management and administration to monitor and adjust technical aspects of iBPMS.

- Registration and repository for searching and reusing process components.

We note that the term ECM brings in its technical definition components that relate to BPMS. The term iBPMS also explicitly refers to ECM components. An analysis of the IT trend research group Forrester (Brocke; Simons; Cleven, 2008) performs a decomposition between types of BPMS suites, according to Figure 2.

The first type of BPMS, exemplified by platforms such as IBM Blueworks, handles knowledge management processes, collaboration among people, and support for workflows in corporate social networks. The second type of BPMS, exemplified by platforms such as Microsoft BizTalk, handles the integration of data sources, applications, local systems, and other enterprises. The third type, which can be exemplified by tools such as IBM FileNet, handles process-centric management focused on document flows and present more advanced document management functions. Types 1 and 3 are BPMS that have a closer relationship with ECM suites.

This intimacy between platforms is very beneficial in bringing synergy to complementary roles in organizations, but it can also bring challenges as to the understanding and correct use within the specific contexts of those organizations. 


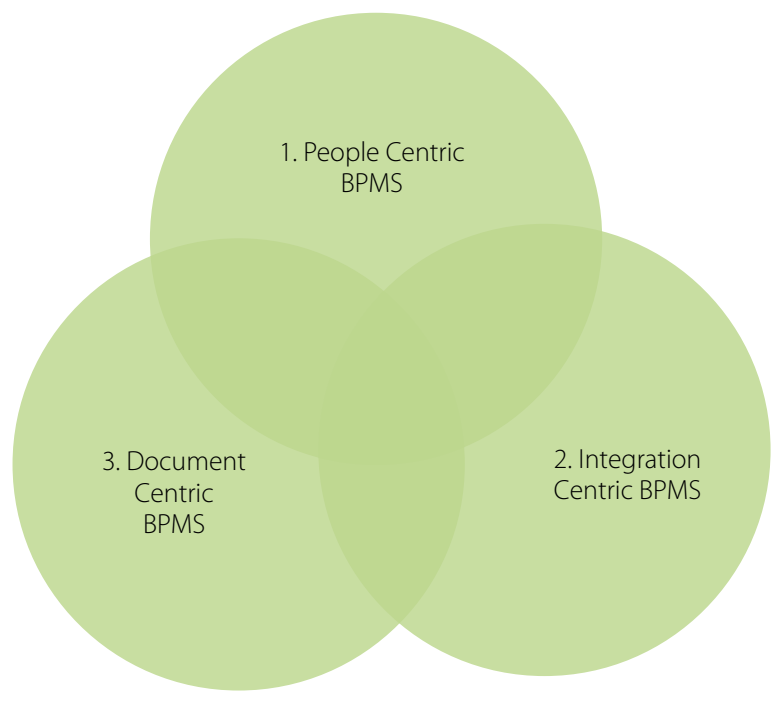

Figure 2. Types of BPMS platforms.

Note: BPMS: Business Process Management Suites/System.

Source: Prepared by Authors (2016).

\section{Discussion}

Definitions of conceptual and technological terms of ECM and BPM in academia and industry are often intertwined. For example, Hooper (2009) defines ECM as a strategy to manage information, assets and process, which seems to encompass process management, a central concern of BPM. In another article, Bill Chambers (2007) points out that it is a mistake to consider BPM and ECM technologies to be very different. The same author points out that ECM tools are increasingly incorporating features of business process management.

Other authors, such as Brocke, Simons and Cleven (2008), acknowledge that ECM initiatives should be driven by BPM frameworks. The author advocates that BPM methodologies are good tools to promote Change Management in organizations. In fact, BPM methodologies usually bring the discipline of People Change Management, a key part of supporting change in people's organizations. The author states that ECM initiatives, which currently have failure rates in implementation of about 50\% (Schulte et al., 2011) tend to have greater chances of success if guided by BPM methods.

Koch (2013) makes an interesting analogy with BPM and ECM initiatives. In this analogy, there is a picture of a highway representing a process and the access and exit ramps are useful for the content to travel in that part of the process.

In a real case of ECM deployment worked by the authors of this article in a public-sector organization, one can observe some interesting aspects in the ECM/BPM (Bax et al., 2015; Zaidan et al., 2015) relationship. The period of observation was close to three years, during which the authors had the opportunity to interact with ECM and BPM working groups. The main facts observed are listed below.

1) In 2013, the organization had an area of records management and document management and an established suite of ECM. The ECM initiative was formally structured in 2004.

2) In 2013 the organization adopted a BPMS suite and deployed a process office in a project completed in 2014. The organization's BPM maturity was incipient in 2015.

3) Still in 2014, process professionals began to incorporate some small documentary flows into the BPMS tool, whose original competence was in the ECM area. 
4) In 2013 and 2014 there was work within a functional area of an ECM initiative that introduced a document management policy, with a document classification plan and a timetable, key archival tools for ECM.

5) Still in 2014, in a work of process improvement nature within a document-originator process, there was the generation of a pilot that brought a strong reduction perspective of document generation for this functional area. This holistic view of BPM and ECM was important, although it was carried out without the involvement of the process office.

6) The BPM and ECM teams of this organization have conceptual differences about the role of each technology platform.

7) Finally, it is important to point out that this organization did not have an established enterprise architecture area in 2015.

The experience in this case study allowed the authors to observe common phenomena regarding the relations between BPM and ECM in this organization, with respect to: (1) Potential conflicts between librarians and archivists on the one hand, and IT engineers and IT teams, on the other, with different visions and different perspectives on how to model documents and processes; (2) Business Process Management and Enterprise Content Management platforms that coexist and compete in almost all business initiatives; (3) Sub-optimal results of ECM initiatives that occur totally apart from the use of BPM methods; (4) The incorporation of document management initiatives by BPM specialists, who are unaware of formal document management tools such as classification plans and timetables, as well as the operationalization of these instruments.

\section{Unifying Instruments}

The segmented view of processes and content can generate waste for organizations. Processes use and generate content. At the same time, content is used and handled by business processes and support. When organizations have process offices and information analysts working in different areas or departments, with poor communication and using incompatible IT frameworks, a negative dynamic system is generated, with potentially bad effects on the use of expected financial resources and business value.

Especially in this scenario, it seems important to have unifying methodological tools that allow complementing the procedural view (HOW) with the content view (WHAT). This article presents three tools that seek to forge a link between BPM and ECM initiatives, while bringing process offices and information analysts together.

\section{Content Management Interoperability Services}

Content Management Interoperability Services (CMIS) is an open standard to allow the exchange of information between content management systems. The CMIS consists of the following components: an ontology that describes its fundamental types and relations, such as repositories, objects, documents, folders, and policies; a standardized set of services for manipulating the types in the ontology, such as repository services, navigation, discovery, and versioning; a standardized query language (CMIS Query Language) for standardized reading access of repositories; a standard set of protocols for information exchange, such as ATOM, JSON, REST and SOAP.

The CMIS standard is born of discussions between stakeholders within AlIM, but it is later standardized by OASIS (Open Standards for the Information Society), in 2010. The most recent version of CMIS (Müller; McVeigh; Hübel, 2013) is 1.1, released in 2012.

Content Management Interoperability Services is designed to be platform independent and flexible enough to be used in different repositories. The CMIS plays a central role in the link between BPM and ECM. While it is possible 
for BPM and ECM technical platforms to talk, the absence of a standard implies in difficulties in communication and portability. The practical effect of the lack of communication standard between BPM and ECM platforms is to strengthen the information silos, which can increase the distance between the various players, i.e., process offices, information analysts, and archivists.

Even in large organizations, where there may be more than one ECM or BPM solutions, the presence of CMIS can maintain interoperability among them, regarding access services to manipulate different documentary types repositories. Figure 3 shows this scenario.

\section{Enterprise Architecture}

Enterprise Architecture (EA) is a discipline that describes organizations in light of conceptual models. With an ontological inclination, it seeks to answer the question of what is an organization in a conceptual point of view, proposing meta-models and models that guide the effort of elaborating a description of the organization integrated into levels: data, processes, physical installations, computational systems, and even strategic motivations.

The integrative aspect is fundamental, as it is a matter of aligning the operational and tactical-technological vision with the strategic view of the business. The ability to integrate the multilevel conceptual models is, therefore, the main differential in relation to the several previous modeling approaches.

Figure 4 presents the Zachman Framework, an ontology for enterprise architectures. In this figure, we can observe vertical and horizontal dimensions. Two vertical dimensions are highlighted here: the QUE WHAT dimension, which deals with the data an organization handles, and the HOW dimension, which essentially handles business processes.

Here, one can observe an integrating model that unifies ECM/WHAT and BPM/HOW within the same conceptual framework. In fact, the enterprise architecture reaches the integration of the generated models through semantics, syntax, and pragmatics, unified and standardized by an ontology.

Traditional modeling approaches, even in BPM and ECM, have always reflected specific aspects of the complex system that is a company, limited to scopes such as strategy, information, process, structure, applications, data, amongst others. Models created in a disintegrated way, each with its specific semantics and syntax, adapted in detail to its scope, and that do not have common interfaces to allow integration.

The concepts of integrated language of a CA are necessarily more generic, since they aim to represent the integration of the organization levels in a model of a higher level of abstraction, primarily directed to communication with decision-makers, directors, superintendents, and managers. Some examples of enterprise architecture knowledge bodies include DODAF, MODAF, TOGAF or PEAF (Urbaczewski; Mrdalj, 2006). One language used to support this level of modeling is the Open Group Archimate (Lankhorst; Drunen, 2007).

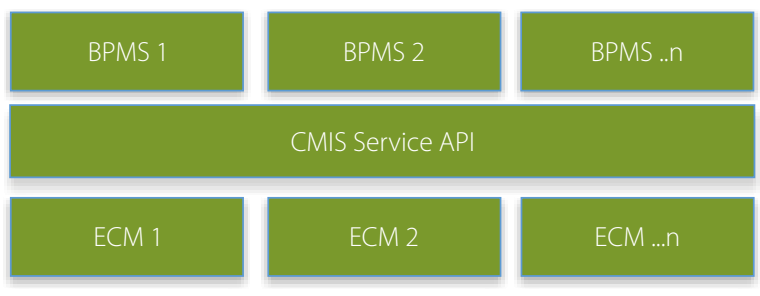

Figure 3. Relations between BPM and ECM with CMIS.

Notes: BPMS: Business Process Management Suites/System; CMIS: Content Management Interoperability Services; ECM: Enterprise Content Management. Source: Prepared by Authors (2016). 


\begin{tabular}{|c|c|c|c|c|c|c|}
\hline & $\begin{array}{l}\text { DATA } \\
\text { What }\end{array}$ & $\begin{array}{c}\text { FUNCTION } \\
\text { How }\end{array}$ & $\begin{array}{l}\text { NETWORK } \\
\text { Where }\end{array}$ & $\begin{array}{l}\text { PEOPLE } \\
\text { Who }\end{array}$ & $\begin{array}{l}\text { TIME } \\
\text { When }\end{array}$ & $\begin{array}{l}\text { MOTIVATION } \\
\text { Why }\end{array}$ \\
\hline $\begin{array}{l}\text { Objective/Scope } \\
\text { (Contextual) } \\
\text { Role: Planner }\end{array}$ & $\begin{array}{l}\text { List of things } \\
\text { important in } \\
\text { the business }\end{array}$ & $\begin{array}{l}\text { List of } \\
\text { Business } \\
\text { Processes }\end{array}$ & $\begin{array}{l}\text { List of } \\
\text { Business } \\
\text { Locations }\end{array}$ & $\begin{array}{l}\text { List of } \\
\text { Important } \\
\text { Organizations }\end{array}$ & $\begin{array}{l}\text { List of } \\
\text { Events }\end{array}$ & $\begin{array}{l}\text { List of } \\
\text { Business Goal } \\
\text { \& Strategies }\end{array}$ \\
\hline $\begin{array}{l}\text { Enterprise Model } \\
\text { (conceptual) } \\
\quad \text { Role: Owner }\end{array}$ & $\begin{array}{l}\text { Conceptual } \\
\text { Data/ } \\
\text { Object Model }\end{array}$ & $\begin{array}{l}\text { Business } \\
\text { Process } \\
\text { Model }\end{array}$ & $\begin{array}{l}\text { Business } \\
\text { Logistics } \\
\text { System }\end{array}$ & $\begin{array}{l}\text { Work } \\
\text { Flow } \\
\text { Model }\end{array}$ & $\begin{array}{l}\text { Master } \\
\text { Schedule }\end{array}$ & $\begin{array}{l}\text { Business } \\
\text { Plan }\end{array}$ \\
\hline $\begin{array}{l}\text { System Model } \\
\text { (logical) } \\
\quad \text { Role:Designer }\end{array}$ & $\begin{array}{l}\text { Logical } \\
\text { Data } \\
\text { Model }\end{array}$ & $\begin{array}{l}\text { System } \\
\text { Architecture } \\
\text { Model }\end{array}$ & $\begin{array}{l}\text { Distributed } \\
\text { Systems } \\
\text { Architecture }\end{array}$ & $\begin{array}{l}\text { Human } \\
\text { Interface } \\
\text { Architecture }\end{array}$ & $\begin{array}{l}\text { Processing } \\
\text { Structure }\end{array}$ & $\begin{array}{l}\text { Business } \\
\text { Rule } \\
\text { Model }\end{array}$ \\
\hline $\begin{array}{l}\text { Technology Model } \\
\text { (physical) } \\
\quad \text { Role: Builder }\end{array}$ & $\begin{array}{l}\text { Physical } \\
\text { Data/Class } \\
\text { Model }\end{array}$ & $\begin{array}{l}\text { Technology } \\
\text { Design } \\
\text { Model }\end{array}$ & $\begin{array}{l}\text { Technology } \\
\text { Architecture }\end{array}$ & $\begin{array}{l}\text { Presentation } \\
\text { Archtecture }\end{array}$ & $\begin{array}{l}\text { Control } \\
\text { Structure }\end{array}$ & $\begin{array}{l}\text { Rule } \\
\text { Desingn }\end{array}$ \\
\hline $\begin{array}{l}\text { Detalied Representatiom } \\
\text { (out of context) } \\
\text { Role: Programmer }\end{array}$ & $\begin{array}{l}\text { Data } \\
\text { Definition }\end{array}$ & Program & $\begin{array}{l}\text { Network } \\
\text { Architecture }\end{array}$ & $\begin{array}{l}\text { Security } \\
\text { Architecture }\end{array}$ & $\begin{array}{l}\text { Timing } \\
\text { Definition }\end{array}$ & $\begin{array}{l}\text { Rule } \\
\text { Speculation }\end{array}$ \\
\hline $\begin{array}{l}\text { Functioning } \\
\text { Enterprise } \\
\text { Role: User }\end{array}$ & $\begin{array}{l}\text { Usable } \\
\text { Data }\end{array}$ & $\begin{array}{l}\text { Working } \\
\text { Function }\end{array}$ & $\begin{array}{l}\text { Usable } \\
\text { Network }\end{array}$ & $\begin{array}{l}\text { Functioning } \\
\text { Organization }\end{array}$ & $\begin{array}{l}\text { Implemented } \\
\text { Schedule }\end{array}$ & $\begin{array}{l}\text { Working } \\
\text { Strategy }\end{array}$ \\
\hline
\end{tabular}

Figure 4. Enterprise Architecture Ontology - Zachman Framework.

Source: WikiPedia (2017).

In terms of the alignment between BPM and ECM, the suggested approach is that first enterprise architecture models be developed. These models allow us to know the most appropriate technical strategy and then define the correct use of BPM and ECM technologies for problems designed and understood by the lens of EA.

\section{Business Capabilities}

Business Capabilities is a construct that represents an organizational arrangement among people, processes, content, and systems used together to deliver a business value to its stakeholders (Cherbakov et al., 2005). A business capability models what a business function accomplishes, i.e. its externally visible behavior (versus how it does it, its internal behavior), and the expected level of performance.

In the context of an educational organization as a university, the ability to "educate students" is an example of this construct. In another example, connected to electric utilities, possible capabilities would be the "transmission of energy" or the "distribution of energy" to its consumers.

Business capabilities have "owners" and "customers", in the generic sense and must perform within a certain level of quality (Marrifield; Tobey, 2006). Maps of capabilities detail how features are implemented at a given point in time, in relation to: the people involved; the operational processes; the data and content manipulated; the technologies, and so on.

At this level of abstraction, we focus on external aspects. How these aspects are achieved is not important in capacity modeling. Capacity is essentially a "black box". Capabilities are descriptive enough to understand how a function fits into the business and what is needed to interact with it. It is summed up enough to provide the 


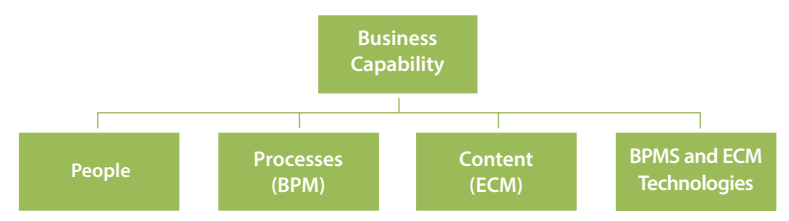

Figure 5. Business capabilities.

Notes: BPM: Business Process Management; BPMS: Business Process Management Suites/System; ECM: Enterprise Content Management.

Source: Prepared by Authors (2016).

stability needed for a firm and lasting foundation. A capability enables you to understand processes and data in an integrated way, and thereby integrate BPM and ECM into a related business function.

Business modeling is predicted in the Archimate language as the construct called the "Business Function". At Archimate, a "business function" can incorporate various business processes, grouping them into business resources based on roles, skills, knowledge, or information.

In terms of BPM and ECM alignments, a conceptual approach can be derived to try to minimize noise between IT teams or even business areas that work with one of these instruments.

1) The establishment of integrative projects to understand, describe, and improve certain business capabilities in an organization.

2) The modeling of business capabilities through instruments such as Business Functions in the Archimate language.

3) The analysis by an enterprise architecture group of the capabilities of the ECM and BPM platforms available in the organization to respond to the modeling business capabilities.

4) The implementation of projects with multidisciplinary teams of BPM and ECM so that the processes and information are harmonically accommodated in a collaborative environment.

That is, the approach appropriately addresses the minimization or reduction of non-ECM BPM projects and non-BPM ECM projects (Figure 5).

\section{Conclusion}

Although BPM and ECM have emerged as separate disciplines and are studied in distinct areas of applied social science, it is imperative to understand the relationship between processes and content in a more formal research perspective. Processes only generate value when manipulating content and, at the same time, content is generated or consumed throughout the organization's processes.

This article seeks to establish the main points of intersection between these disciplines, providing an integrative conceptual vision that allows process offices, information analysts, librarians, and archivists to work together synergistically. Some conceptual tools able to promote such integration have been presented. CMIS, the first of these tools, is a key technology to reduce the communication impedance between BPM platforms and ECM repositories. CMIS also allows different ECM tools to interoperate. Enterprise Architecture practices are another tool in this regard, as they seek to enclose several dimensions of an organization within an ontology to represent forms of integration between content and processes within unifying conceptual models.

The third and last tool presented is the concept of Business Capability Maps. Capabilities allow expressing the primary business functions of organizations. Because these constructs are formed by the arrangement of people, processes, information, and information technologies, they also naturally link BPM processes with ECM data and information into cohesive sets. 
All authors contributed to the conception and design of the study, data analysis and final editing.

\section{References}

Antonucci, Y. L. et al. Guide to the Business Process Management Body of Knowledge (BPM $\left.C B O K^{\oplus}\right)$. Chicago: Association of Business Process Management Professionals, 2009.

Bax, M. P. et al. A gestão de conteúdo corporativo em empresa do setor elétrico: um relato de caso. In: Encontro Nacional de Pesquisa em Ciência da Informação - Enancib 2015, 16., 2015, João Pessoa. Anais... João Pessoa: Ancib, 2015.

Brocke, J.; Simons, A.; Cleven, A. A business process Perspective on enterprise content management: Towards a framework for organizational change. [S.I.]: ECIS, 2008.

Chambers, B. BPM: How does it fit into an ECM strategy. AlIM E-DOC, v. 21, n. 2, p. 36-39, 2007.

Cherbakov, L. et al. Impact of service orientation at the business level. IBM Systems Journal, v. 44, n. 4, p. 653-668, 2005.

Gartner Group. Gartner, Next Generation of BPM. Gartner Business Process Management Summit 2012. London: Gartner Group, 2012.

Hooper, D. Enterprise content management: Definition please. Infonomics, v. 23, n. 4, p. 56, 2009.

International Organisation For Standardisation. ISO 15489-1: Information and Documentation - Records Management Part 1 - General, International Organisation for Standardisation. Geneva: ISO, 2001.

Koch, W. Cinquenta tons de verde. Information Management, n. 34, p. 40, 2013.

Lankhorst, M.; Drunen, H. V. Enterprise architecture development and modelling: Combining TOGAF and ArchiMate. Via Nova Architectura, p. 1-16, 2007. Available from: <http://api.ning.com/files/1vDSdWV6JAgpNXvLL9hU3121jW Mxztv9AzOogrfwJLi-U79-UyYIlu1 II34yynga44xabZUmLaOd AiTUJx1/1K8btmziOt3N/Lankhorst.pdf>. Cited: Nov. 23, 2015.

Larrivee, B. A holistic approach to digital transformation: AllM White Paper. Silver Spring: AllM, 2016. Available from: <https://www.swisspostsolutions.com/en/whitepaper/aiimwhite-paper---a-holistic-approach-to-digital-transformation. pdf>. Cited: Oct. 25, 2017.

Marrifield, R.; Tobey, J. Motion Lite: A rapid application of the business architecture techniques used by Microsoft motion. Indonesia: Microsoft, 2006. Available from: <https://www. microsoft.com/indonesia/msdn/motionlite.aspx>. Cited: Nov. 23, 2015.

Müller, F.; McVeigh, R.; Hübel, J. OASIS: Content Management Interoperability Services (CMIS). Version 1.1. Burlington: Oasis, 2013. (Technical Report). Available from: <http://docs.oasisopen.org/cmis/CMIS/v1.1/os/CMIS-v1.1-os.html>. Cited: Nov. 23, 2015.

Schulte, R. et al. The trend toward intelligent business operations. Stamford: Gartner Group, 2011.

Silva, C. R. M.; Martins, S. R. The Next generation for business process management systems and its technological implications. [S.I.]: AISeL, 2013.

Smith, H.; Fingar, P. Business process management: The third wave. Tampa: Meghan-Kiffer Press, 2003.

Urbaczewski, L.; Mrdalj, S. A comparison of enterprise architecture frameworks. Issues in Information Systems, v. 7, n. 2, p. 18-23, 2006.

Wikipedia Contributors. Zachman Framework. Wikipedia - the free encyclopedia. Sept. 2017. Available from: <https://en. wikipedia.org/w/index.php?title=Zachman_Framework \&oldid=801328873>. Cited: Oct. 27, 2017.

Zaidan, F. et al. Quão estratégica pode ser a gestão arquivística de documentos? Aportes da arquitetura corporativa. In: Encontro Nacional de Pesquisa em Ciência da Informação - Enancib 2015, 16., 2015, João Pessoa. Anais... João Pessoa: Ancib, 2015. 